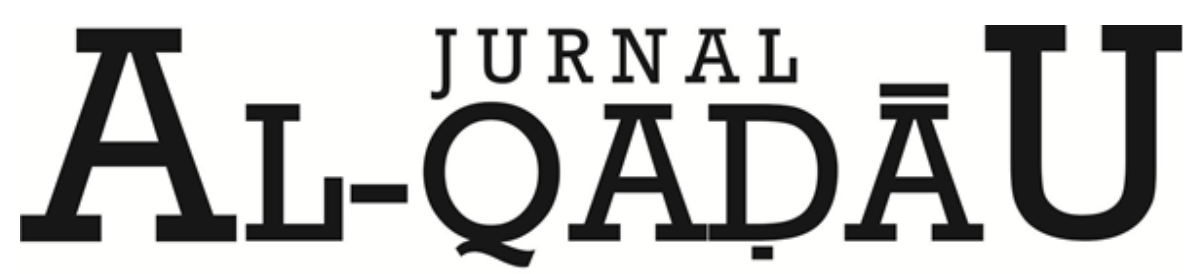

PERADILAN dan HUKUM KELUARGA ISLAM

\title{
Belis dalam Perkawinan Masyarakat Islam Lamaholot di Flores Timur Perspektif Hukum Islam
}

\author{
Belis in the Marriage of Lamaholot Islamic Society in East Flores of the Islamic Law \\ Perspective
}

\author{
Ahmad Asif Sardari \\ Universitas Islam Negeri Alauddin Makassar \\ Email: achievgates24 gmail.com
}

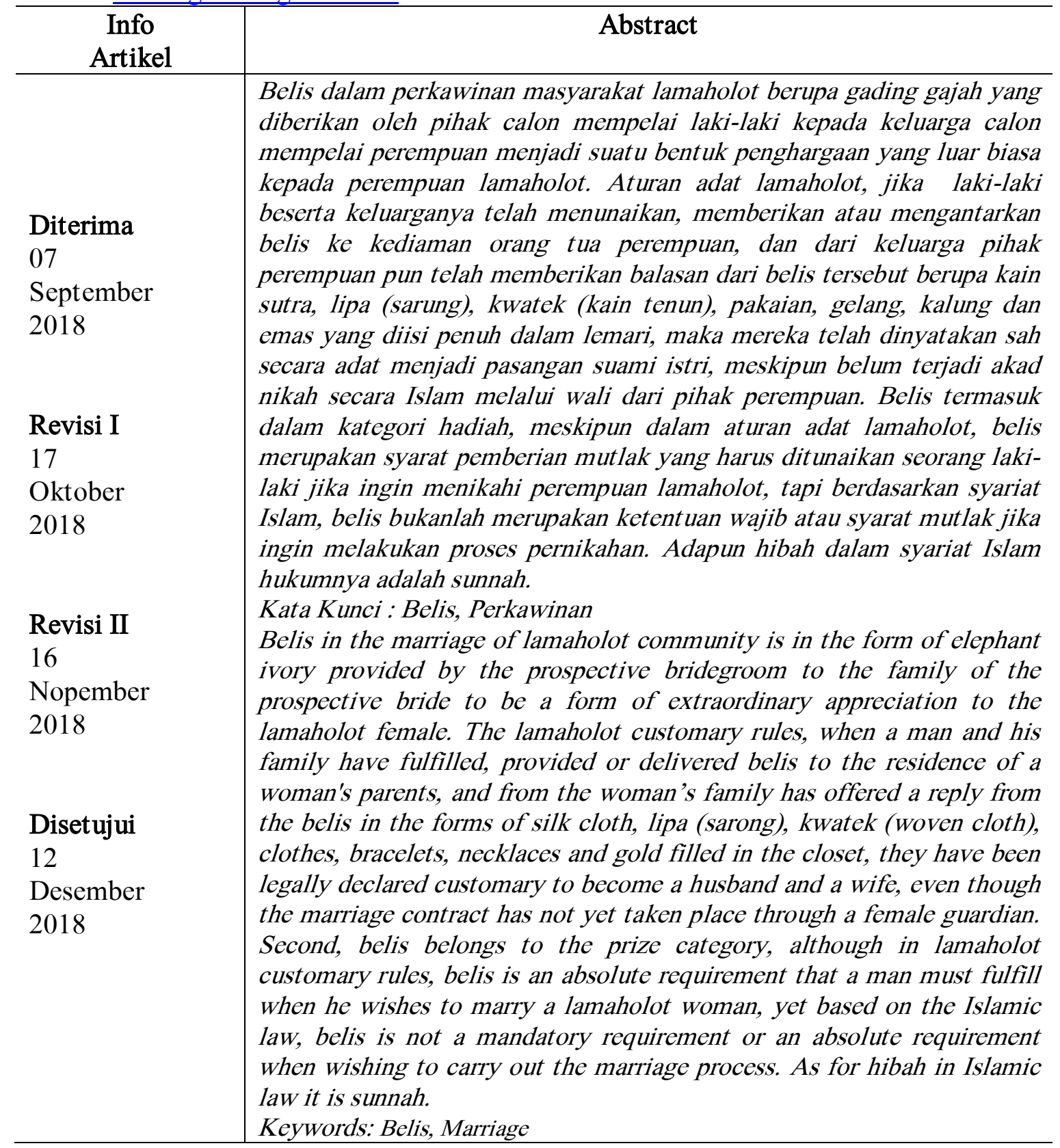




\section{A. PENDAHULUAN}

Hukum merupakan seperangkat aturan yang mengatur hubungan antara manusia yang satu dengan lainnya dalam kehidupan bermasyarakat. Hukum tersebut terdiri dari norma atau kaidah, baik tertulis maupun tidak tertulis sehingga diperlukan kriteria tertentu dalam sikap, tindak atau perilaku manusia guna mencapai kedamaian melalui keserasian antara ketertiban dan ketentraman, atau antara disiplin dan kebebasan. ${ }^{1}$ Secara sederhana hukum diartikan seperangkat peraturan tentang tingkah laku manusia yang diakui oleh suatu negara atau kelompok masyarakat, berlaku dan mengikat untuk anggotanya. ${ }^{2}$ Hal ini bertujuan agar kehidupan manusia berlangsung damai, adil, dan sejahtera.

Sebelum lahirnya UU RI tentang perkawinan, mengenai ketentuan, tata cara dan sahnya suatu perkawinan bagi orang Indonesia pada umumnya didasarkan pada hukum agama dan hukum Adat masing-masing. Menurut hukum Adat, perkawinan adalah suatu ikatan antara seorang laki-laki dengan seorang perempuan untuk membentuk rumah tangga yang dilaksanakan secara Adat dan agamanya dengan melibatkan keluarga kedua belah pihak saudara maupun kerabat. ${ }^{3}$

Setiap daerah di Indonesia ketika melangsungkan proses perkawinan selalu dipenuhi dengan suasana yang sangat sakral dan kental. Hal ini disebabkan oleh kekuatan adat yang secara turun-temurun dipercayai oleh masyarakat Indonesia sebagai suatu hal yang wajib dilaksanakan oleh masyarakat. Hal tersebut juga berlaku di daerah kabupaten Flores Timur, Provinsi Nusa Tenggara Timur. Adat sangat mendominasi dalam sebuah proses perkawinan, salah satunya dalam hal pemberian belis masyarakat Lamaholot di Flores Timur. Dalam kehidupan keseharian pelapisan sosial yang memandang wanita sebagai sentral kehidupan masyarakat dan tinggi nilainya. Karena itu, meski masyarakat menilai seorang wanita tidak secara material, mereka tetap mencari materi pembanding dalam bentuk belis.

Proses meminang gadis di kalangan suku Lamaholot, kabupaten Flore Timur, Nusa Tenggara Timur, unik. Meski penduduk wilayah ini tidak memelihara gajah dan mata pencaharian mereka kebanyakan petani dan nelayan, gading gajah sudah menjadi belis sejak ratusan tahun lalu. Dalam masyarakat Lamaholot, belis selalu menimbulkan masalah rumit. Pembicaraan paling alot antara pihak keluarga perempuan dan laki-laki adalah soal berapa banyak gading gajah harus diberikan pihak laki-laki sebagai belis bagi calon istri. Status sosial menjadi ukuran menentukan jumlah dan ukuran gading.

Calon istri berasal dari keluarga dengan status sosial tinggi, jumlah gading jauh lebih banyak dan lebih panjang. Kalau anak gadis berasal dari keluarga sederhana, jumlah dan ukuran gading bisa dikompromikan. Jumlah gading untuk meminang seorang perempuan berkisar antara 1 dan 7 batang. Jumlah tujuh batang biasanya berlaku di kalangan bangsawan atau orang terpandang. Masyarakat biasa umumnya tiga batang. Harga gading gajah bervariasi, yaitu Rp 13 juta sampai Rp 100 juta per batang tergantung ukurannya.

\footnotetext{
${ }^{1}$ Soerjono Soekanto, Efektivitas Hukum dan Peranan Sanksi (Cet. I; Bandung: Remaja Rosdakarya, 1985), h. 1.

${ }^{2}$ Amir Syarifuddin, Ushul Fikih (Jakarta: Logos Wacana Ilmu, 2000), h. 21.

${ }^{3}$ Soerjono Wignjodipoere, Asas-asa Hukum Adat (Jakarta : Gunung Agung, 1988). h. 55.
} 
Hakekat belis adalah menunjang harkat seorang wanita dalam kehidupan patrilineal, dan agar keluarga wanita mendapat tempat terhormat dihadapan keluarga pria. Bagi masyarakat Lamaholot, kedudukan wanita adalah kedudukan seorang ibu. Selain itu, belis juga sebagai lambang pemersatu keluarga pria dan wanita, sekaligus sebagai tanda seorang perempuan resmi pindah ke suku suami. Karena itu perempuan Lamaholot dimata kaum pria selalu mendapat perlindungan dalam pergaulan sosialnya. Setiap pelabelan negatif yang dilakukan terhadap perempuan Lamaholot dapat dikenakan denda adat bagi pelakunya. Bentuk dendanya bisa berupa gading, sarung tenun adat atau lainnya. Dendanya sangat berfariasi sesuai jenis pelanggaran dan permintaan keluarga perempuan. ${ }^{4}$

\section{B. METODE PENELITIAN}

Untuk membahas permasalahan tersebut dilakukan pengumpulan data dengan sistem library research (kepustakaan) dan field research (penelitian lapangan) yang bersifat deskriptif kualitatif, dengan mengambil lokasi di Kecamatan Witihama, Kelubagolit, dan Ile Boleng Kabupaten Flores Timur. Pendekatan yang digunakan adalah pendekatan yuridis normatif dan pendekatan sosiologis. Adapun pengumpulan data yang diperoleh di lapangan dengan teknik observasi, wawancara, dan dokumentasi diolah menggunakan analisis reduksi data, penyajian data dan penarikan kesimpulan.

\section{PEMBAHASAN}

\section{Praktik Belis Dalam Perkawinan Masyarakat Islam Lamaholot Di Flores Timur}

\section{Sejarah Belis}

Berdasarkan cerita-cerita dari orang tua dulu, mereka mengatakan bahwa belis/gading gajah itu muncul ketika pasukan-pasukan Portugis datang mencoba untuk menjajah Nusantara. Ketika mereka datang untuk mengeksploitasi pulau Flores, di dalam perahu-perahu mereka terdapat banyak gading gajah yang sangat asing menurut warga Flores, karena disana memang tidak terdapat hewan gajah. Lambat laun, ketika seorang pria ingin meminang seorang perempuan, gading gajah pun menjadi sesuatu yang sakral untuk diberikan kepada keluarga perempuan dambaannya sebagai sesuatu yang sakral yang wajib diberikan kepada keluarga perempuan sebagai pengganti karena sang lelaki akan menikahi anak perempuan yang telah dibesarkan dari kecil oleh orang tuanya yang akan berpindah suku dan tanggung jawab dari pihak orang tua kepada calon suaminya setelah menikah nantinya. ${ }^{5}$

\section{Makna filosofis dari Belis}

Gading gajah dinilai sebagai simbol yang tepat karena merupakan benda yang istimewa yang tidak banyak dimiliki oleh orang lain dan sangat sulit untuk didapatkan. Gading gajah dianggap seperti marwah kebarek lamaholot (perempuan lamaholot) yang sangat dihormati dan diistimewakan. Gading gajah juga dianggap sebagai simbol bahwa kebarek lamaholot tidak mudah untuk didapatkan dan dinikahi begitu saja. Gading gajah juga dianggap sebagai pelindung kehormatan kebarek lamaholot

\footnotetext{
${ }^{4}$ Kabarindonesia.com/berita.php?pil=20\&jd=Marginalisasi + Perempuan + dalam + Perkawinan + Lamaholot $\& d n=20110520082349$, (diakses pada tanggal 17 januari 2018)

${ }^{5}$ Karim Kopong Keda, Guru, Wawancara, Witihama, 20 April 2018.
} 
sehingga tidak mudah untuk dipermainkan begitu saja oleh para lelaki. Gading gajah dipandang sebagai unsur penting dalam pernikahan lamaholot karena memiliki nilainilai luhur serta sebagai simbol pemersatu laki-laki dan perempuan. ${ }^{6}$

Gading gajah tidak hanya sebagai pengikat hubungan perkawinan antara suami istri, atau antara keluarga laki-laki, tetapi seluruh kumpulan masyarakat lamaholot di suatu wilayah. Perkawinan itu memiliki nilai sakral yang meluas, suci, dan bermartabat yang lebih sosialis. Gading gajah merupakan simbol penghargaan tertinggi terhadap seorang gadis yang hendak dinikahi. Penghargaan atas kepercayaan, kejujuran, ketulusan, keramahan yang dimiliki oleh perempuan lamaholot. ${ }^{7}$

\section{Manfaat Belis Gading Gajah}

Menunaikan belis, selain untuk menggugurkan tanggung jawab adat yang telah dibebankan kepada kita ketika ingin menikahi perempuan lamaholot, menunaikannya juga turut mengangkat derajat orang tua dan mertua kita dihadapan adat dan masyarakat luas. Mengangkat derajat suku kita, baik kepada suku keluarga perempuan, juga suku-suku lain yang turut menerapkan adat lamaholot. Menyepelekan ketentuan ini juga akan berdampak sebaliknya. Orang tua, mertua, suku kita akan dipandang sebelah mata oleh masyarakat luas dan dihadapan adat, oleh karena itu, beban itu akan terasa jika seorang laki-laki yang menikahi perempuan lamaholot belum menunaikan kewajiban adat ini. ${ }^{8}$

Belis selain memiliki manfaat yang bisa dirasakan dari luar yakni dari masyarakat, penerapan belis ini juga akan memberikan mamfaat yang berasal dari dalam/internal keluaarga, yakni mempererat ikatan kekeluargaan antara keluarga kedua belah pihak mempelai yang tersatukan melalui ikatan perkawinan. Karena otomatis keluarga kedua mempelai akan mempunyai ikatan kekeluargaan antar keduabelah pihak. Melalui pemberian belis ini, akan menciptakan hubungan yang harmonis antara keluarga keduabelah pihak. ${ }^{9}$

Berdasarkan penjelasan-penjelasan tersebut, dapat disimpulkan bahwa manfaat dari pemberian belis dalam perkawinan masyarakat Islam lamaholot adalah sebagai berikut:

1) Martabat keluarga laki-laki dan perempuan menjadi terhormat.

2) Menghargai harkat dan martabat perempuan lamaholot

3) Pihak keluarga perempuan akan merasa dihargai

4) Menciptakan hubungan timbal balik antar kedua keluarga mempelai

5) Meningkatkan rasa solidaritas secara internal antar masing-masing keluarga kedua mempelai

6) Memupuk semangat gotong royong antar keluarga kedua mempelai.

\section{Jenis-jenis Belis}

1) Bala wahan (bala pertama): bala belee (gading besar dan panjang) dengan panjang satu depa (rentangan tangan) orang dewasa batasannya sampai di kala ketekke' (pergelangan tangan)

\footnotetext{
${ }^{6}$ Karim Kopong Keda, Guru, Wawancara, Witihama, 20 April 2018.

${ }^{7}$ Arsyad Demon, Wirausaha, Wawancara, Ile Boleng, 18April 2018.

${ }^{8}$ Arsyad Demon, Wirausaha, Wawancara, Ile Boleng, 18April 2018.

${ }^{9}$ Karim Kopong Keda, Guru, Wawancara, Witihama, 20 April 2018.
} 
2) Bala ke ruheng (bala kedua): bala kelikene (setengah depa sampai pergelangan tangan)

3) Bala ke telung (bala ketiga): bala kewayane (setengah siku sampai siku)

4) Bala ke pat (bala keempat): bala ina umene (setengah depa sampai batas bahu)

5) Bala ke lema (bala kelima): bala opu lake (setengah depa, persis bela dada tangan)

6) Bala ke nem (bala keenam): bala kepalik papa (lipatan sikut sampai ke belahan dada)

7) Bala ke pito (bala ketujuh): bala waluk pao/bala lempar mangga (dari ujung jari tengah pertama sampai lipatan sikut)

Masing-masing belis tersebut memiliki fungsi pemberian. Ketika seorang lakilaki ingin menikahi perempuan lamaholot yang berasal dari keturunan yang terhormat, laki-laki tersebut harus siap memberikan belis yang lebih banyak. Jika perempuan tersebut dihargai dengan tujuh belis, maka tiga gading merupakan pemberian pokok yang harus diberikan yang terdiri dari bala kewahang, keruheng dan ketelung. Bala kepat diperuntukan untuk membalas air susu ibu yang tetlah diberikan kepada anak perempuannya, bala kelema untuk keluarga bapak dari perempuan tersebut, bala kenem diperuntukan kepada paman/saudara perempun dari ibu mempelai perempuan, bala kepito diperuntukkan kepada keluarga sesuku yang telah ikut menyumbang berbagai barang untuk menyandang belis yang akan diberikan oleh pihak laki-laki. ${ }^{10}$

\section{Aspek-aspek yang Mewajibkan Pemberian Bala}

Belis dalam bentuk gading gajah dalam adat lamaholot sangat erat kaitannya dengan proses perkawinan. Bala menjadi syarat mutlak yang harus ditempuh oleh seorang lelaki jika ingin meminang wanita pujaan hatinya, bala juga mempunyai nilai yang sangat sakral dalam kehidupan bermasyarakat dan dapat membentuk nilai sosial yang tinggi yakni sebagai peningkatan harkat dan martabat kaum wanita lamaholot.

Selain untuk aspek perkawinan masyarakaat lamaholot, dikenal juga gadinggading lain yang harus diberikan oleh pihak laki-laki kepada pihak perempuan kerena adanya pelanggaran dari kesepakatan yang telah disepakati dalam urusan perkawinan. Dalam adat lamaholot, pada peristiwa roi bala (pihak laki-laki didatangi oleh pihak perempuan untuk menagih belis) ada ungkapan seperti ini: "kirin pai kalo tite tobo paken taan melan uen ana welin bala. Naku marin kopong (jika pemudanya bernama kopong) nabe taka lanke barek (jika perempuannya bernama barek) welin bala lema naan mai nihi : barek welin bala telo, bala temakane telo, buka pita bala tou". (jika perkawinan ini berjalan sesuai dengan prosedur adatnya, maka belisnya ada tiga. Tapi oleh karena perkawinan tidak sesuai dengan prosedur, maka dua gading gajah sebagai denda, yakni satu gading untuk denda membawa lari anak gadisnya, dan satu gading untuk buka pintu/menutup aib.) Hal tersebut merupakan contoh peristiwa jika sang lelaki membawa kabur anak gadis mereka. ${ }^{11}$

\footnotetext{
${ }^{10}$ Arsyad Demon, Wirausaha, Wawancara, Ile Boleng, 18 April 2018.

${ }^{11}$ Karim Kopong Keda, Guru, Wawancara, Witihama, 20 April 2018.
} 
Ahmad Asif Sardari

\section{Pelaksanaan Belis dalam Perkawinan Masyarakat Islam Lamaholot di Flores Timur 1. Persiapan sebelum Lamaran}

a. Menyiapkan Bala (Gading Gajah) yang Dijadikan sebagai Belis

Sebagai syarat mutlak dalam proses perkawinan adat lamaholot, sudah sepantasnya bala menjadi perhatian utama yang harus disiapkan oleh pihak laki-laki ketika ingin menikahi perempuan lamaholot. Tanpa adanya persiapan yang matang tentang hal ini, pihak laki-laki akan mengalami kesulitan dalam merealisasikan niat baiknya. Karena masyarakat lamoholot sangat kental dengan adat istiadatnya, maka ketentuan adat seperti ini pun akan sangat berpengaruh dan sudah seharusnya tidak boleh disepelekan.

Gading gajah itu sendiri diperjual belikan di pasar. Meskipun jarang dan sulit ditemukan, tapi praktik jual beli itu ada. Jika kesulitan mendapatkan gading gajah, baik karena harganya yang terlalu mahal ataupun keberadaannya yang sulit untuk ditemui, biasanya pihak laki-laki meminjam bala (gading gajah) dari kerabatnya yang memiikinya untuk menyelesaikan formalitas adat yang dibebani kepadanya. ${ }^{12}$

b. Memperhatikan status sosial perempuan di masyarakat

Bentuk dan jumlah belis yang akan diberikan oleh pihak laki-laki ke pihak perempuan sangat bergantung pada status sosial perempuan dan keluarganya dalam masyarakat. Hal tersebut menjadi predikat adat yang menentukan berapa banyak dan ukuran belis yang harus ditunaikan laki-laki jika ingin menyunting perempuan lamaholot.

c. Menyiapkan hewan-hewan tambahan sebagai pelengkap belis

Meskipun bersifat sebagai tambahan, tapi hewan-hewan ternak sudah menjadi satu kesatuan yang tidak bisa dilepaskan dengan bala pada belis perkawinan masyarakat lamaholot. Kualitas tambahan hewan ternak pada paketan belis perkawinan masyarakat lamaholot akan menjadi salah satu patokan keluarga perempuan dalam merespon lamaran pihak laki-laki.

Hewan-hewan tambahan ini akan menjadi patokan pihak perempuan dalam menyandangi belis yang telah diberikan berupa kain sutra yang harganya kisaran 25.000.000, lipa (sarung), kwatek (kain tenun) pada kisaran 250.000-500.000 pakaian, gelang, kalung dan emas yang diisi penuh dalam lemari sebagai bentuk balasan belis yang telah diberikan yang total keseluruhannya berkisar antara 50.000.000$60.000 .000 . .^{13}$

\section{d. Musyawarah antar suku}

Adat lamaholot sangat menekankan kebersamaan antar suku. Karena, menurut adat lamaholot, meskipun tidak memiliki hubungan darah tetapi jika berasal dari suku yang sama, berarti merupakan saudara, saudara yang selayaknya memiliki tanggung jawab yang sama. Karena perempuan merupakan harta suku, maka untuk menyambutnya, sudah sepantasnya melibatkan suku dalam hal ini. Oleh karena itu diperlukan koda adat (musyawarah internal suku) untuk membahas segala kesiapannya dan strategi sebelum lamaran.

\footnotetext{
${ }^{12}$ Arsyad Demon, Wirausaha, Wawancara, Ile Boleng, 18 April 2018

${ }^{13}$ Arsyad Demon, Wirausaha, Wawancara, Ile Boleng, 18 April 2018
} 
Musyawarah ini juga menghadirkan semua bineng (saudara perempuan berdasarkan suku) untuk menghitung-menghitung berapa gading yang sudah pernah digunakan dalam pernikahan antara suku tersebut, antara binengnya dengan opu lake (saudara laki-laki dari pihak perempuan). Kegiatan kalkulasi ini sangat penting untuk menghitung kekuatan belis yang dimiliki oleh suku pihak laki-laki. ${ }^{14}$

\section{Proses Lamaran}

Proses lamaran dalam adat lamaholot merupakan proses yang menentukan apakah pihak laki-laki diterima atau diizinkan untuk menikahi perempuan dari pihak perempuan ini. ${ }^{15}$

Proses lamaran dalam adat lamaholot selain sebagai bentuk pernyataan keinginan untuk menikahi, juga merupakan proses pembicaraan adat dalam menetukan hari perkawinan dan juga menunjukan belis dalam bentuk gading dan tambahan hewan ternaknya yang sudah disiapkan oleh pihak laki-laki ke keluarga pihak perempuan sebagai syarat mutlak dalam perkawinan masyarakat lamaholot. Diperoses lamaran ini juga akan diketahui apakah belis dari pihak laki-laki akan diterima oleh pihak perempuan ataukah tidak, beserta dengan tawaran belis yang seharusnya dari pihak perempuan jika belis yang disiapkan oleh pihak laki-laki itu tidak sesuai. Mulai dari jenis dan ukuran balanya beserta dengan jumlah tambahan hewan ternaknya. Dalam proses ini, terjadi pembicaraan adat mengenai belis perempuan ini.

Apabila semua persyaratannya sudah sesuai, atau jika ada penyanggupan dari pihak laki-laki, maka pembicaraan adatnya akan lancar-lancar saja tanpa ada perdebatan yang alot dan lamarannya akan diterima. Namun jika belisnya tidak sesuai, maka akan terjadi tawar menawar belis serta perdebatan yang alot untuk mencari jalan keluar dan untuk mempertemukan argumen dari kedua belah pihak. Jika tidak ada kesepakatan, bisa jadi lamaran itu tidak diterima, dan perkawinan pun terancam batal.

\section{Pembayaran Belis}

Proses pembayaran atau pemberian belis secara resmi berdasarkan adat lamaholot dari pihak laki-laki kepada keluarga pihak perempuan setelah terjadinya kesepakatan terhadap jenis dan jumlah belis beserta tambahan hewan ternaknya ketika proses lamaran berlangsung.

Aturan adat lamaholot, jika laki-laki beserta keluarganya telah menunaikan, memberikan, atau mengantar belis tersebut ke kediaman orang tua perempuan, dan dari keluarga pihak perempuan pun telah memberikan balasan dari belis tersebut berupa kain sutra, lipa (sarung), kwatek (kain tenun), pakaian, gelang, kalung dan emas yang diisi penuh dalam lemari, maka mereka telah dinyatakan sah secara adat menjadi pasangan suami istri, meskipun belum terjadi akad nikah secara Islam melalui wali dari pihak perempuan. Pasca pembayaran belis tersebut, kemudian keluarga kedua belah pihak membicarakan dan menetukan urusan agamanya beserta dengan acara resepsinya. ${ }^{16}$

Tata cara pembayaran belis dalam perkawinan masyarakat lamaholot dapat dilakukan dengan berbagai cara. Diantaranya sebagai berikut:

\footnotetext{
${ }^{14}$ Arsyad Demon, Wirausaha, Wawancara, Ile boleng, 18April 2018

${ }^{15}$ Karim Kopong Keda, Guru, Wawancara, Witihama, 20 April 2018

${ }^{16}$ Karim Kopong Keda, Guru, Wawancara, Witihama, 20 April 2018
} 
a. Secara tunai

Kesanggupan dari pihak keluarga laki-laki dalam membayaran, menunaian, menyerahkan belis kepada keluarga perempuan secara langsung karena telah mencapai kesepakatan pada penawaran belis ketika keluarga kedua belah pihak bertemu dan membicarakan tentang belis pada proses lamaran, sedangkan dari pihak keluarga perempuan pun telah tersediah balasan dari belis tersebut berupa kain sutra, lipa (sarung), kwatek (kain tenun), pakaian, gelang, kalung dan emas yang diisi penuh dalam lemari.

b. Utang

Keberadaan belis di daratan lamaholot makin lama mengalami kelangkahan. Selain susah untuk didapatkan, jika ada harga yang ditawarkan pun sangat mahal. Karena hal-hal ini, sehingga pembayaran belis pun bisa dilakukan dengan utang. Cara seperti ini lebih banyak ditempuh oleh para kebarak (pemuda) lamaholot karena situasi tersebut. Dan belis ini juga ada kemungkinan akan habis dari hasil perkawinan antar suku yang sama oleh generasi setelahnya, mengingat perempuan merupakan harta milik suku, jadi kemungkinan ini bisa terjadi. ${ }^{17}$

Pertimbangang lainnya ialah, umur terus berlanjut, kehidupan harus terus berlanjut, jika menunggu sampai belis tersebut mampu ditunaikan, maka akan menghambat niat suci untuk menanggungjawabi perempuan idamannya, menyempurnakan agama, dan mengarungi bahtra kehidupan secara bersama.

Pengakuan dari pihak laki-laki yang diperlukan sebagai bentuk kepastian dan keputusan bahwa belisnya akan ditunaikan, meskipun bentuk fisiknya belum bisa ditunjukkan bahkan diberikan kepada keluarga pihak perempuan.

Bentuk pengakuannya bahwa sang lelaki harus menyatakan kesediaannya untuk memberikan belis tersebut kelak. Biasanya sang lak-laki menjanjikan waktu dalam menunaikan belis tersebut untuk meyakinkan pihak keluarga perempuan tentang kesungguhan hatinya, atau menyatakan bahwa kelak keturunannya lah yang akan membayar belis tersebut jika selama hidupnya dia mengalami kesulitan dalam menunaikannya.

Pihak laki-laki harus memperhatikan bahasa yang digunakan dalam memberikan kepastian tentang penunaian belis tersebut ke pihak keluarga perempuan. Dengan menggunakan bahasa adat yang jelas dan jujur agar proses penagihan belis nantinya akan berjalan sesuai dengan pengakuan yang telah dibuat sebelumnya. Karena jika salah, tidak jelas, bahkan tidak jujur dalam menggunakan bahasa adat, tujuan belis yang salah satunya untuk mempererat hubungan kekeluargaan diantara kedua belah pihak dalam bentuk perkawinan bisa tidak tercapai. ${ }^{18}$

Kebiasaan unik yang biasa terjadi dalam pembayaran belis secara utang ini, biasanya dari pihak laki-laki membawa belis pinjaman dari kerabat lain atau dari suku lain sebagai bentuk formalitas adat agar masyarakat luas mengetahui bahwa pasangan keluarga tersebut telah menunaikan proses adat pernikahan. Kebiasaan ini dikenal dengan dengan istilah "pana rerrong bali remma", yang dalam bahasa lamaholotnya memiliki arti "berangkat siang pulangnya malam". Ketika telah sepakat tentang

\footnotetext{
${ }^{17}$ Arsyad Demon, Wirausaha, Wawancara, Ile Boleng, 18 April 2018

${ }^{18}$ Arsyad Demon, Wirausaha, Wawancara, Ile Boleng, 18 April 2018
} 
belisnya, dan tentu berdasarkan sepengetahuan pihak keluarga perempuan, bahwa pihak laki-laki belum memiliki bentuk fisik dari gading tersebut, maka untuk menunaikan prosesi adat agar masyarakat luas mengetahui bahwa kedua belah pihak telah melaksanakan kewajiban adatnya, biasanya keluarga laki-laki membawa belis yang dipinjam dari pihak lain ke keluarga perempuan dengan sepengetahuan dari pihak keluarga perempuan. Setelah itu, ketika pihak laki-laki selesai dengan proses adatnya, belis yang dibawah tadi oleh pihak laki-laki, dibawa pulang kembali beserta dengan perempuan tersebut karena dianggap telah sah menikah secara adat. Dibawa pulangnya kembali belis yang diberikan pihak laki-laki terhadap perempuan, bukan berarti pembayaran belisnya telah selesai ditunaikan. Pihak laki-laki tetap harus memberikan belisnya kelak jika sudah ada. ${ }^{19}$

\section{c. Cicil}

Cara pembayaran seperti ini berlaku bagi pria yang ingin menikahi perempuan yang memiliki status sosial yang tinggi dalam adat lamaholot, yang mengharuskan laki-laki membayarkan belis lebih dari satu, sedangkan pihak laki-lakinya tidak mampu untuk menyanggupi belis itu secara keseluruhan pada waktu itu. Tawaran adatnya ialah dengan memberikan satu Belis yang disanggupi pihak lakai-laki tersebut diawal sebagai jaminan dan sebagai bentuk pengakuan bahwa mereka sanggup untuk menjalani tanggung jawab adat yang dibebankan dalam bentuk belis, dan sisa belisnya bisa ditunaikan ketika pihak laki-laki telah behasil mendapatkannya.

\section{d. Barter}

Cara pembayaran ini berlaku untuk jenis belis gading hidup. Tidak semuanya harus menggunakan gading gajah sebagai belis. Jika kita tidak mampu dewasa bisa menggantikan mamannya diposisi keluarganya. Karena menurut adat lamaholot, belis digunakan sebagai bentuk penghormatan kepada perempuan, digunakan untuk menebus anak perempuan jika ingin diambill dari keluarganya untuk dijadikan istri. Jadi, kita menggantikan belis kita berupa gading gajah itu dengan anak perempuan kita nantinya jika dia telah menjadi perempuan dewasa. ${ }^{20}$

\section{Pendapat dan Harapan untuk Praktek Belis Kedepannya}

Belis merupakan perkara adat. Masyarakat lamaholot sangat kental dengan ketentuan-ketentuan adatnya. Dalam perihal belis, bukan termasuk mahar dalam suatu perkawinan, karena tidak diberikan kepada perempuan, melainkan kepada orang tuanya yang kemudian menjadi harta suku. Dan yang menentukan jumlah belis yang harus diberikan sudah termasuk ketentuan adat, ketentuan suku. Sudah sangat jelas bahwa belis bukan merupakan bagian dari syariat Islam. ${ }^{21}$

Ketentuan belis merupakan salah satu upaya adat untuk menjaga kehormatan perempuann lamaholot, yang mampu mempersatukan dua pihak keluarga menjadi satu keluarga, mempersatukan dua suku besar. Kondisi zaman sekarang semakin kesini semakin berkembang, semakin modern. Kekhawatiran akan tersingkirnya adat istiadat

\footnotetext{
${ }^{19}$ Bukhari Syarif, Pegawai Kecamatan Kelubagolit, Wawancara, Kelubagolit, 19 Februari 2018.

${ }^{20}$ Arsyad Demon, Wirausaha, Wawancara, Ile Boleng, 18April 2018.

${ }^{21}$ Ahmad Daramnto, Kepala KUA Kecamatan Kelubagolit, Wawancara, Kelubagolit 23
} Februari 2018. 
yang telah hidup sejak dulu pasti ada. Terlebih lagi semakin kesini, gading gajah semakin sulit ditemukan. ${ }^{22}$

Tujuan dari belis memang sangat baik. Dengan diterapkannya belis, harkat dan martabat perempuan lamaholot dapat terjaga. Namun, kesulitan untuk mendapatkan gading gajah di era sekarang ini dan mahalnya harga dari gading, membuat masyrakat lamaholot khususnya laki-laki mengalami kesulitan untuk mendapatkannya. ${ }^{23}$

\section{Pandangan Hukum Islam terhadap Belis dalam Perkawinan Masyarakat Islam Lamaholot di Flores Timur Presentase Islam di Lamoholot}

Data Umat Beragama Kecamatan Ile Boleng Tahun 2017

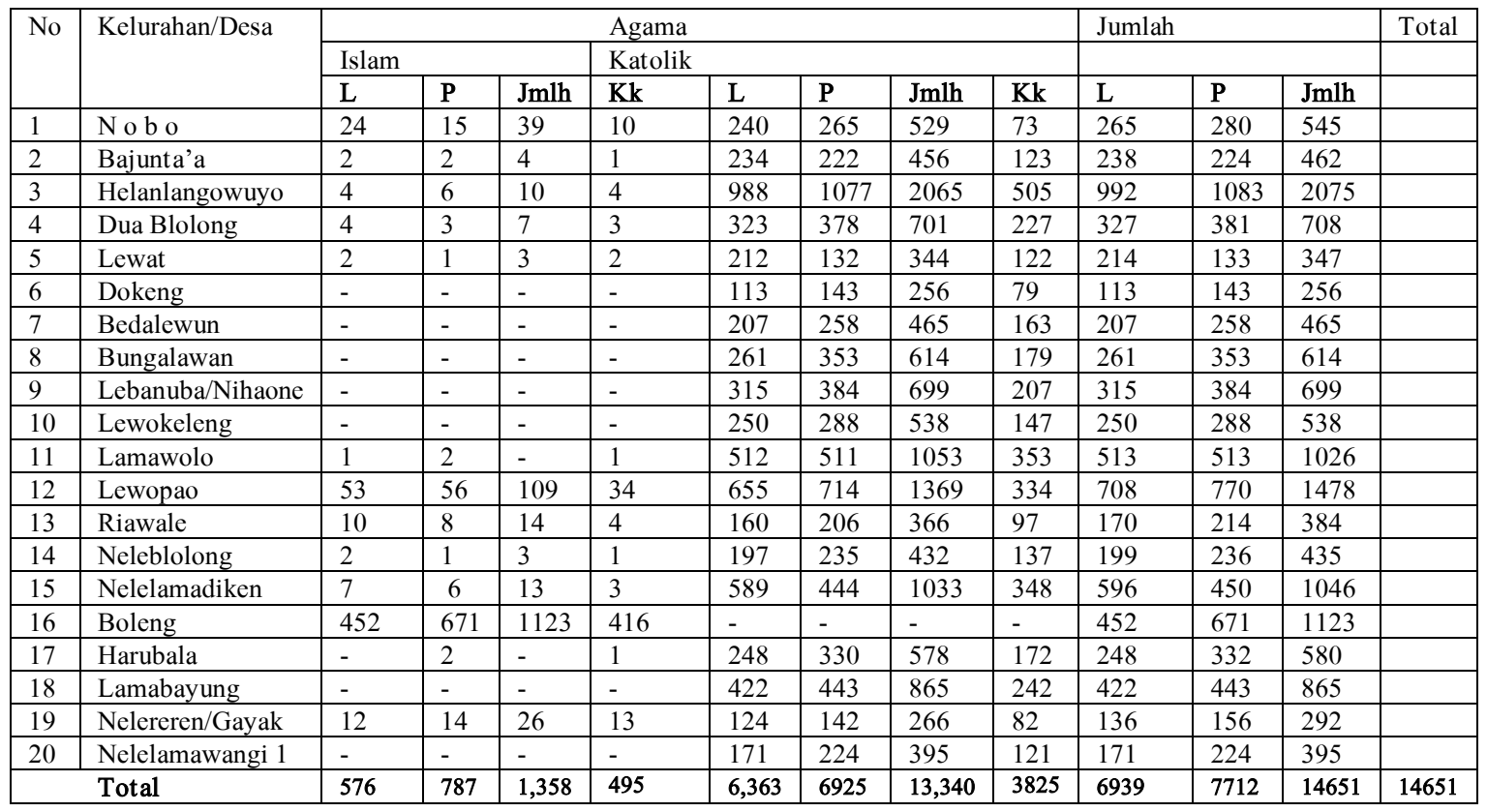

Data Umat Beragama Se-Kecamatan Kelubagolit Kabupaten Flores Timur Tahun 2018

\begin{tabular}{|c|c|c|c|c|c|c|c|c|c|}
\hline \multirow[t]{3}{*}{ No } & \multirow{3}{*}{ Kelurahan/Desa } & \multicolumn{8}{|c|}{ Agama } \\
\hline & & \multicolumn{3}{|c|}{ Islam } & \multicolumn{5}{|c|}{ Katolik } \\
\hline & & $\mathrm{L}$ & $\mathrm{P}$ & Jmlh & $\mathrm{Kk}$ & $\mathrm{L}$ & $\mathbf{P}$ & Jmlh & Kk \\
\hline 1 & HORINARA & 223 & 181 & 391 & 412 & 803 & 205 & 294 & 499 \\
\hline 3 & MUDA & 9 & 152 & 14 & 19 & 33 & 237 & 260 & 497 \\
\hline 4 & SUKUTOKAN & 81 & 788 & 104 & 103 & 207 & 376 & 412 & 788 \\
\hline 7 & REDONTENA & 50 & 334 & 76 & 99 & 175 & 512 & 595 & 1107 \\
\hline 8 & ADOBALA & 8 & 118 & 6 & 14 & 20 & 287 & 313 & 600 \\
\hline 9 & PEPAK GEKA & 71 & 276 & 107 & 106 & 213 & 474 & 506 & 980 \\
\hline 10 & LAMBUNGA & 165 & 248 & 410 & 470 & 880 & 490 & 596 & 1086 \\
\hline & Total & 796 & 3151 & 1392 & 1539 & 2931 & 3925 & 4614 & 8539 \\
\hline
\end{tabular}

Data Umat Beragama Se-Kecamatan Witihama Kabupaten Flores Timur Tahun 2018

\begin{tabular}{|l|l|l|}
\hline ISLAM & KATOLIK & JUMLAH \\
\hline 3.523 & 15.893 & 19.416 \\
\hline
\end{tabular}

${ }^{22}$ Karim Kopong Keda, Guru, Wawancara, Kitihama, 20 April 2018

${ }^{23}$ Bukhari Syarif, Pegawai Kecamatan Kelubagolit, Wawancara, Kelubagolit, 19 Februari 2018 
Table tersebut mempresentasikan Jumlah masyarakat Islam yang mempraktikan belis dalam perkawinan berdasarkan adat lamaholot. Berdasarkan persentasinya, nominal masyarakat Islam lamaholot tersebut lebih rendah dibandingkan masyarakat katolik. Masyarakat Islam di Nusa Tenggara Timur secara umum memang hidup sebagai kalangan minoritas, meskipun demikian, terdapat juga di beberapa desa yang secara kuantitas masyarakat Islamnya lebih banyak dari pada masyarakat katoliknya. Masyarakat lamaholot mampu hidup dengan tentram dan damai ditengah beragamnya agama dan disatukan dengan adat lamaholot yang diterapkan dan dipatuhi secara penuh oleh setiap masyarakatnya.

Esensi dari pada belis dalam perkawinan masyarakat lamaholot, perempuan berada pada suatu sisi yang pantas kita perlakukan secara makruf. Makruf yang dalam pandangan adat lamaholot agar kita perlakukan secara istimewah, lemah lembut, dan perlu untuk kita lindungi. Belis juga bertujuan agar laki-laki betul-betul memperlakukan perempuan dengan sepantasnya, dengan penuh kasih sayang, karena untuk berhasil memilikinya secara utuh, seorang laki-laki harus memperjjuangkannya dengan susah payah dalam bentuk pemberian belis kepada keluarga perempuan.

Pandangan tersebut membuat masyarakat lamaholot tetap mempertahankan belis sebagai upaya mempertahankan tradisi yang telah dilaksanakan sejak lama oleh para leluhur mereka, dan sebagai sarana menciptakan keluarga yang rahmat hingga akhir hayat dalam ikatan keluarga yang kuat.

Belis dalam perkawinan masyarakat lamaholot bukanlah mahar sebagai syarat perkawinan dalam syariat Islam. Belis merupakan bagian dalam ketentuan adat berupa pemberian wajib bagi pihak laki-laki kepada keluarga pihak perempuan jika ingin menikahi perempuan lamaholot. Dalam istilah fiqhi, belis termasuk dalam kategori hadiah, meskipun dalam aturan adat lamaholot, belis merupakan syarat pemberian mutlak yang harus ditunaikan seorang laki-laki jika ingin menikahi perempuan lamaholot, tapi berdasarkan syariat Islam, belis bukanlah merupakan ketentuan wajib atau syarat mutlak jika ingin melakukan proses pernikahan. Adapun hibah dalam syariat Islam hukumnya adalah sunnah. ${ }^{24}$

Agama sangat menghormati adat yang berlaku, oleh karena itu adat semestinya mengandung unsur-unsur agama didalamnya. Karena, terdapat kaidah ushuliah yang menjelaskan bahwa adat itu dapat dijadikan hukum. Adat yang pastinya tidak bertentangan dengan nilai-nilai Islam.

Praktek belis yang diterapkan oleh masyarakat Islam lamaholot memiliki aspek yang sangat memberatkan dalam menerapkannya dan menunaikannya merupakan suatu kesulitan. Meskipun dalam menerapkannya bisa ditunaikan dengan cara utang secara turun temurun, namun beban ini akan terus ada hingga anak cucu kita sampai mereka bisa menunaikannya. Harga sebatang gading gajah yang sangat tinggi, dan keberadaan dari gading gajah inipun sangat susah untuk didapatkan. Aspek-aspek inilah kemudian yang memberatkan dalam melaksanakannya.

Terlepas dari segala aspek negatif yang didapatkan dari ketentuan adat ini, terdapat pula aspek-aspek positif yang didapatkan dari penerapan adat ini, aspek-aspek

${ }^{24}$ Aliy As'ad, Tarjamah Fathul Mu'in, Jilid I (Jakarta: Menara Kudus, 1980), h. 328 
yang sangat Islami dalam melindungi kehormatan wanita sekaligus mengangkat harkat dan martabat perempuan lamaholot. Ketentuan-ketentuan yang mampu mencegah seorang laki-laki untuk menodai kehormatan perempuan lamaholot, melanggar perjanjian-perjanjian kesetiaan dalam perkawinan lamaholot, serta kesepakatankesepakatan adat yang telah disepakati ketika seorang laki-laki ingin menikahi perempuan lamaholot. Kesemua ketentuan-ketentuan adat tersebut jika dilanggar, maka akan dikenakan denda berupa belis dengan ukuran tertentu sesuai dengan keinginan keluarga perempuan dan harus ditunaikan secara tunai tanpa harus diutang.

Belis diharapkan agar bisa lebih dipermudah lagi, karena belis merupakan bagian dari perkawinan berdasarkan adat lamaholot, sedangkan perkawinan dalam Islam cenderung dipermudahkan dalam proses pelaksanaannya agar ketentuanketentuan adat bisa tetap berlaku tanpa melunturkan nilai-nilai Islami yang ada didalamnya. Apalagi jika ada seorang laki-laki dengan niat baik dan tulus ingin menikahi gadis lamaholot, sudah selayaknya juga kita dapat membantu agar niat baik tersebut dapat terealisasi tanpa adanya hambatan-hambatan yang bisa melunturkan apalagi sampai membatalkan niat baik tersebut. Belis dalam bentuk gading gajah dalam perkawinan masyarakat Islam lamaholot diharapkan bisa disederhanakan lagi jumlahnya atau bahkan dikonversikan dalam bentuk uang yang tidak berlebihan nominalnya ataupun bentuk lain sesuai dengan kesepakatan keluarga kedua belah pihak. Sanksi-sanksi adat yang diberlakukan sebagai bentuk antisipatif terhadap tindakan-tindakan asusila yang dapat menimpa perempuan-perempuan lamaholot diharapkan bisa tetap diterapkan, karena dampak tersebut bisa dirasakan sampai saat ini dimana perempuan lamaholot tetap terjaga kehormatannya dan martabatnya sangat dihargai dan dihormati.

\section{PENUTUP}

\section{Kesimpulan}

Setelah menguraikan mengenai belis dalam perkawinan masyarakat Islam lamaholot di Flores Timur perspektif hukum Islam, peneliti memperoleh beberapa kesimpulan sebagai berikut :

1. Belis dalam perkawinan masyarakat lamaholot berupa gading gajah yang diberikan oleh pihak calon mempelai laki-laki kepada keluarga calon mempelai perempuan menjadi suatu bentuk penghargaan yang luar biasa kepada perempuan lamaholot. Bala (gading gajah) dianggap sebagai marwahnya perempuan lamaholot dan sebagai simbol pengikat dalam perkawinan masyarakat lamaholot. Aturan adat lamaholot, jika laki-laki beserta keluarganya telah menunaikan, memberikan, atau mengantar belis tersebut ke kediaman orang tua perempuan, dan dari keluarga pihak perempuan pun telah memberikan balasan dari belis tersebut berupa kain sutra, lipa (sarung), kwatek (kain tenun), pakaian, gelang, kalung dan emas yang diisi penuh dalam lemari, maka mereka telah dinyatakan sah secara adat menjadi pasangan suami istri, meskipun belum terjadi akad nikah secara Islam melalui wali dari pihak perempuan. Pasca pembayaran belis tersebut, kemudian keluarga kedua belah pihak membicarakan dan menetukan urusan agamanya beserta dengan acara resepsinya.

2. Terlepas dari segala aspek negatif yang didapatkan dari ketentuan adat ini, terdapat pula aspek-aspek positif yang didapatkan dari penerapan adat ini, aspek-aspek yang sangat Islami dalam melindungi kehormatan wanita sekaligus mengangkat harkat 
dan martabat perempuan lamaholot. Ketentuan-ketentuan yang mampu mencegah seorang laki-laki untuk menodai kehormatan perempuan lamaholot, melanggar perjanjian-perjanjian kesetiaan dalam perkawinan lamaholot, serta kesepakatankesepakatan adat yang telah disepakati ketika seorang laki-laki ingin menikahi perempuan lamaholot. Kesemua ketentuan-ketentuan adat tersebut jika dilanggar, akan dikenakan denda berupa belis dengan ukuran tertentu sesuai dengan keinginan keluarga perempuan dan harus ditunaikan secara tunai tanpa harus diutang. Sanksi adat tersebut merupakan reaksi dari adat dan masyarakat dan bentuk antisipasi bagi mereka yang ingin atau akan melakukan tindakan asusila.

\section{Implikasi}

1. Budaya lamaholot yang sudah ada bersesuaian dengan ketentuan syariat Islam wajib untuk dipertahankan. Sedangkan yang tidak sesuai, dapat disesuaikan tanpa meninggalkan nilai budaya lamaholot itu sendiri.

2. Belis diharapkan agar bisa lebih dipermudah, karena belis bagian dari perkawinan berdasarkan adat lamaholot, sedangkan perkawinan dalam Islam cenderung dipermudahkan dalam proses pelaksanaannya agar ketentuan-ketentuan adat bisa tetap berlaku tanpa melunturkan nilai-nilai Islami yang ada didalamnya.

\section{DAFTAR PUSTAKA}

Abdullah, Abd. Gani. Himpunan Perundang-Undangan dan Peraturan Peradilan Agama Jakarta: Intermasa, 1991.

Abdullah, Boedi Cs. Perkawinan Perceraian Keluarga Muslim. Bandung: Pustaka Setia, 2013.

Abidin, Slamet dan Aminuddin. Fiqih Munakahat I. Bandung : CV Pustaka Setia, 1999.

Agoes, Artati. Kiat Sukses Menyelenggarakan Pesta Perkawinan Adat Jawa (Gaya Surakarta dan Yogyakarta). Jakarta, Gramedia Pustaka Utama, 2010.

Alhamdani, H.S.A. Risalah Nikah, Hukum Perkawinan Islam. Cet. III; Jakarta: Pustaka Amani, 1989.

Ali, Zainuddin. Metode Penelitian Hukum. Jakarta: Sinar Grafika, 2010.

As'ad, Aliy, Tarjamah Fathul Mu'in. Jilid I. Jakarta: Menara Kudus, 1980.

Azwar, Saifuddin. Metode Penelitian. Yogyakarta: Pustaka Pelajar, 2003.

Basyir, Ahmad Azhar. Hukum Perkawinan Islam. Yogyakarta: Penerbit Perpustakaan Fak. Hukum UII Yogyakarta, 1996.

Bungin, Burhan. Analisis Data Kualitatif: Pemahaman Filosofi dan Metodologi ke Arah Penguasaan Model Aplikasi. Jakarta: Rajawali Pers, 2009

Darajad, Zakiyah. Ilmu Figh, Jilid II. Yogyakarta: Dana Bhakti Wakaf, 1995.

Ghozali, Abdul Rahman. Fiqh Munakahat. Jakarta: Prenada Media Group, 2003.

Hadikusuma, Hilman. Hukum Perkawinan Adat. Cet. II; Bandung; Alumni, 1983.

Hadikusuma, Hilman. Hukum Perkawinan Indonesia menurut Perundangan, Hukum Adat, Hukum Agama. Bandung, Mandar Maju, 2007.

Hakim, Abdul Hamid. Mabadi Awwaliyyah, Juz I. Cet. I; Jakarta: Bulan Bintang, 1976. 
Al-Jaziry, Abdurrahman. Kitâb al-Fiqh 'ala Mazâhib al-Arbâ'ah, Jilid VII. Mesir: Dâr al-Irsyad, t.th.

Jumali, R. Abdul. Hukum Islam. Bandung: CV. Mandar Maju, 1999.

Al-Jurjawi, Ali Ahmad. Hikmah al-Tasyri wa Falsafatuh (Filsafat dan Hikmah Hukum Islam), (Terjemah). Semarang: CV. Asy-Syifa, 1992.

Kansil, C.S.T. Pengantar Ilmu Hukum dan Tata Hukum Indonesia. Cet. VIII; Jakarta : Balai Pustaka, 1989.

Kementerian Agama RI. Al-Quran dan Terjemah. Bandung: Syāmil Qur'an, 2012.

Moleong, Lexi J. Metodologi Penelitian Kualitatif. Bandung: Remaja Rosdakarya, 2010.

Mughniyah, Muammad Jaad. Fiqih Lima Madzhab. Jakarta: PT. Lentera Basritama, 2004.

Muhajir, Neong. Metedologi Penelitian Kualitatif. Yogyakarta: Rake Selatan, 1998.

Narbuko, Cholid dan Abu Ahmadi. Metodologi Penelitian. Jakarta: Bumi Aksara, 2007.

Nonci. Adat Pernikahan Masyarakat Makassar dan Tana Toraja. Makassar: Aksara, 2003.

Prawirohamidjojo, R.Soetojo. Pluralisme dalam Perundang-undangan Perkawinan di Indonesia. Surabaya: Airlangga University Press, 2002.

Purwadi. Upacara Tradisional Jawa, Menggali Untaian Kearifan Lokal. Yogyakarta: Pustaka Pelajar, 2005.

Pusat Bahasa Departemen Pendidikan Nasional. Kamus Besar Bahasa Indonesia Edisi III. Jakarta: Balai Pustaka, 2001

Qamar, Nurul. Perbandingan Sistem Hukum dan Peradilan. Cet. I; Makassar: IKAPI, 2010.

Rafiq, Ahmad. Hukum Islam di Indonesia. Jakarta: Rajawali Pers, 1998.

Ramulyo, Moh. Idris. Hukum Perkawinan Islam. Jakarta : Bumi Aksara, 1999.

Riduan, Metode dan Teknik Menyusun Proposal Penelitian. Bandung: Alfabeta, 2009.

Rifai. Muhammad. Klausal Kifâyatul Akhyâr (Terjemah). Semarang: Toha Putra, t.th.

Ruma, Marzuki Wahiddan. Fiqh Mazhab Negara, Kritikatas Politik Hukum Islam di Indonesia. Yogyakarta: LKIS, 2001.

Rusyd, Ibnu. Bidâyah al-Mujtahîd wa Nihâyah al-Muqtasîd, Jilid I. Bairut: Dâr al-Fikr, t.th.

Sabiq, Sayyid. Fiqh Sunnah Jilid II. Cet. IV; Bairut: Dār al-Fikr.

Sahrani, Sohari dan Tihami. Fikih Munakahat: Kajian Fikih Nikah Lengkap. Jakarta; PT. Raja Grafindo, 2009.

Shihab, M.Quraish. Membumikan Al-Qur'an. Bandung: Mizan, 1999.

Saleh, K. Wantjik. Hukum Perkawinan Indonesia. Jakarta Timur: Ghalia Indonesia, 1982.

Soekanto, Soerjono. Efektivitas Hukum dan Peranan Sanksi. Cet. I; Bandung: Remaja Rosdakarya, 1985. 
Sudarsono. Pokok-pokok Hukum Islam. Cet.1; Jakarta: Rineka Cipta, 1992.

Sukanto, Suryono. Hukum Adat Indonesia. Jakarta: Rajawali, 1986

Sukmadinata, Nana Syaodih. Metode Penelitian Pendidikan. Bandung: Remaja Rosdakarya, 2008.

Sugiono. Metodologi Penelitian Pendidikan Pendekatan Kuantitatif, Kualitatif dan $R \& D$. Bandung: Alfabeta, 2010.

Syarifuddin, Amir. Ushul Fikih. Jakarta: Logos Wacana Ilmu, 2002.

Syarifuddin, Amir. Hukum Perkawinan Islam di Indonesia. Jakarta: Kencana Prenada Media Group, 2009.

Wignjodipoere, Soerjono. Asas-asa Hukum Adat. Jakarta : Gunung Agung, 1988.

Wahid, Marzuki dan Rumadi. Fiqh Mazhab Negara, Kritik atas Politik Hukum Islam di Indonesia. Cet. I; Yogyakarta: LKIS, 2001.

Yunus, Mahmud. Hukum Perkawinan dalam Islam. Jakarta: PT Hidakarya Agung, 1985

Zakiyah. Ilmu Fiqh, Jilid II. Yogyakarta: Dana Bhakti Wakaf, 1995.

Al-Zuhaili, Wahbah. al-Fiqh al-Islami wa Adillatuh. Cet. III; Bairut: Dâr al-Fikr, 1989. 